\title{
Personal Remarks
}

Claus Kreß

Member of the Law Faculty of the University of Cologne

Magnifizenz,

Spectabilis,

dear guests of honour,

dear Faculty,

and above all dear Don!

We will now soon have reached the climax of this ceremony - Benjamin Ferencz' words addressed to us. We shall hear from a conversation that I had the immense privilege and pleasure to have with Ben about a week ago. By introduction, Donald Ferencz will convey a message from Ben to us.

Before passing the floor to you, Don, for that happy purpose, please allow me to very briefly add a personal note to the fine addresses we have just heard. Among the many impressive facets of Ben's personality which have just been duly mentioned, there is one which I wish to highlight: It is Ben's power to inspire the youth. This power is essentially based on two things: his charisma and his love for the young people, at least for those young people with idealism.

In his recent book, whose title "Parting Words" I believe, Don, we should continue rejecting, there is a passage which tells you a lot about Ben. I wish to cite it to you:

"I hope my story might be of some inspiration to others, and it certainly can be. But one person's story is not enough to keep that belief burning, and a person who looks like you, sounds like you, is from the same place you come from, will likely be worth more to you.

Seek out those people and their stories and fall back on them when your ambitions seem doubtful, or challenges have presented themselves. Struggling toward your hopes and dreams - whatever they may be - can make you feel like you're treading water out at sea.

Building up a network of stories that prove others like you have done it before can help you see that there are foundations beneath you so tall, it's as if you are standing on the battlement of a castle. 
And when you become a person who does the impossible, share your story widely so that others who look at you and sound like you can believe in themselves, too."

Ben has been acting in this spirit. Over more than twenty years, I have been observing Ben working behind and on the scenes of international negotiations. He has given advice to countless decision-makers, he has submitted or worked on countless drafts and has addressed countless highest-ranking audiences. It should therefore come as no surprise that he has always been busy. Actually, to the question how he is, he has only recently responded: "I am busy like hell".

Yet, Ben has never been too short of time to spare a few moments for a conversation with a young student of law. And no more than a few moments are necessary for him to set fire at such an occasion, that is, to enflame the passion of a young lawyer for getting ready to take up the candle from him, Ben, to carry it further. There are many great international lawyers around the globe, scholars, politicians, State officials or activists who feel Ben's continuing inspiration in their work. I am one of those scholars. Ben was an important adviser to Germany's delegation at the Rome Conference on the establishment for the International Criminal Court. Although I was the most junior member of the delegation, Ben spared some moments with me, showed respect as he has invariably been doing, and so I got a sense for his exceptional charisma. Over the course of the years to follow, the few moments have grown into many and the exchange with Ben has become a crucial source of inspiration for me, one that I now try to share with my students. Over all these years, Ben has become a fatherly friend and an important teacher. This is why this important moment for my Faculty is also a very precious one for me personally. I should be grateful, Don, if you would include this personal note in the report about this short ceremony that I am sure you will pass on to your father.

But before so reporting, dear Don, the floor is now yours to convey Ben's message to us.

\section{Reference:}

Benjamin Ferencz with Nadia Khomani, Parting Words. 9 Lessons for a Remarkable Life (sphere 2020). 